\title{
The Effect of Fertilisation on the Performance of Barlinka Table Grapes on Sandy Soil, Hex River Valley*
}

\author{
D. Saayman and J.J.N. Lambrechts \\ Department of Soil and Agricultural Water Science, University of Stellenbosch, 7600 Stellenbosch, South Africa
}

Submitted for publication: September 1995

Accepted for publication: October 1995

Key words: Grapevine, Vitis vinifera, fertilisation, nitrogen, phosphourus

\begin{abstract}
The response of Barlinka table grapes on grayish, sandy soil to irrigation-applied $\mathbf{N}$ fertilisation levels, patterns of $\mathbf{N}$ application, crop load and stock $P$ and $K$ fertilisation, were evaluated over a 12-year period in the Hex River Valley. Under the conditions of the trial, an $\mathrm{N}$ level of about $100 \mathrm{~kg} \mathrm{ha}^{-1}$ appeared to be optimum for shoot growth and grape quality. Bunch and crop mass benefited from increased $\mathrm{N}$ levels, apparently due to better berry set. Increased $\mathrm{N}$ levels also appeared to preserve greenness of bunch stems better during cold storage but $\mathrm{N}$ levels higher than $105-120 \mathrm{~kg} \mathrm{ha}^{-1}$ reduced colour and sugar content of berries. Applying $67 \%$ of total seasonal $N$ during the pre-bloom to veraison period and the rest after harvest, as against a 50:50 distribution, had a slight, positive effect on shoot growth and bunch size, again apparently caused by better berry set. Indications of a small, positive response of shoot growth to stock $P$ fertilisation were obtained. Potassium applied in this manner was found to be ineffective due to leaching and regular irrigation-applied $K$ fertilisation had to be adopted. Increased crop load had a marked negative effect on shoot growth and grape quality, in the latter case comparable in magnitude to that of too high $\mathrm{N}$ levels. A balanced crop load of 22 bunches per vine with a shoot mass of $1,822 \mathrm{~kg}$, was calculated for this trial, but a crop load of 18-19 bunches per vine appeared to be the maximum that still ensured the best quality.
\end{abstract}

The fertilisation of vines often appears to be a subject of conflicting opinion, probably because of difficulties encountered in obtaining reliable results with fertilisation in practice as well as under controlled experimental conditions (Delas, 1992). This is not too surprising when viewed in the light of the vine's perennial nature, its obvious hardiness, deep rooting nature, long season in which to acquire the nutrients needed and the varying ability of different soils to supply these nutrients (Malherbe, 1962; Winkler et al., 1974; Champagnol, 1978a).

Amongst the macro-elements, nitrogen $(\mathrm{N})$ is the element which is the most likely to give a response, mainly in terms of improved vigour. Champagnol (1971) found that $\mathrm{N}$ always has a positive effect on vegetative growth but that yield is only increased in the case of low vigour cultivars like Aramon and not in the case of vigorous cultivars like Carignan. Nitrogen fertilisation decreases photosynthetic intensity and increases respiration intensity, a reflection of stimulated metabolism.

Lacking convincing experimental fertilisation results, earlier attempts at arriving at recommendations adopted an indirect approach. According to Delmas (1971), Muntz started calculating the removal of elements by French vineyards since 1895 and arrived at an amount of 30-50 kg N ha-1 $\mathrm{yr}^{-1}$ for Bordeaux vineyards, with variations depending on cultivar, locality and vintage. Delmas (1971) proposed N needs of $50-60 \mathrm{~kg} \mathrm{~N}^{-1}$ $\mathrm{yr}^{-1}$ for high-quality vineyards $\left(50-60 \mathrm{hL} \mathrm{ha}^{-1}\right.$ production) and $90-110 \mathrm{~kg} \mathrm{~N} \mathrm{ha}^{-1} \mathrm{yr}^{-1}$ for high-production vineyards.

In Charente, Lafon et al. (1965) found a $67 \mathrm{~kg} \mathrm{~N} \mathrm{ha}^{-1}$ uptake by leaves, shoots and bunches of Ugni blanc for a production of $120 \mathrm{hL} \mathrm{ha}^{-1}$ (about $20 \mathrm{t} \mathrm{ha}^{-1}$ ). This $\mathrm{N}$ uptake peaks at flowering and stops at veraison when shoot growth stops, with a strong migration of $\mathrm{N}$ and potassium $(\mathrm{K})$ from leaves to bunches during ripening. This pattern was different from that found for warmer regions like the Midi in France and North Africa, where $\mathrm{N}$ uptake recommences during ripening. This was ascribed to differences in cultivars and climate. For a production of $160 \mathrm{hL} \mathrm{ha}^{-1}\left(26-27 \mathrm{t} \mathrm{ha}^{-1}\right)$ and assuming that leaves return to the soil, $\mathrm{N}$ exporation was calculated at $37 \mathrm{~kg} \mathrm{ha}^{-1}$. This small amount and the long period of uptake implied that many soils would naturally be able to supply the amounts of $\mathrm{N}$ needed.

For Alsace and a production of $74 \mathrm{hL} \mathrm{ha}^{-1}$, Marocke et al. (1977) calculated mean $\mathrm{N}$ uptake by leaves, shoots and crop of $54 \mathrm{~kg} \mathrm{ha}^{-1}$, with $69 \%$ diverted to the vegetative parts and the rest to the crop. Based on a fertilisation trial with Gewürztraminer on granitic soil, they come to the same conclusion as their colleagues in Germany, namely that only elements exported need to be replaced for the majority of situations. According to Schaller \& Löhnertz (1991), Wagener first published data on grapevine nutrition in Germany in 1917, recommending $140 \mathrm{~kg} \mathrm{~N} \mathrm{ha}^{-1}, 20 \mathrm{~kg}$ phosphourus $(\mathrm{P}) \mathrm{ha}^{-1}$ and $100 \mathrm{~kg} \mathrm{~K} \mathrm{ha}^{-1}$ for quantity production and $95 \mathrm{~kg} \mathrm{~N} \mathrm{ha}^{-1}$, $15 \mathrm{~kg} \mathrm{P} \mathrm{ha}^{-1}$ and $70 \mathrm{~kg} \mathrm{~K} \mathrm{ha}^{-1}$ for quality production. However, there is little evidence that this was the basis for fertilisation between the two world wars.

From 1950 German agriculture, including viticulture, was reconstructed with the emphasis on production, resulting in high fertilisation levels. Pollutions of rivers caused growing concern and fertilisation levels of vineyards remained virtually a secret, although Gärtel pub-

*Part of a Ph. D. (Agric.) dissertation by the senior author to be submitted to the University of Stellenbosch.

Acknowledgements: Sincerest appreciation to the Nietvoorbij Research Institute for funds and use of infrastructure, and in particular to Me.A.E. Theron for technical assistance and data processing. Also to the former Fruit Technology Research Institute (presently INFRUITEC) and Dr. I.M. Terblanche for the establishment of the experimental vineyard. 
lished recommendations, based on old data, of $80-130 \mathrm{~kg}$ $\mathrm{N} \mathrm{ha}^{-1}, 40-50 \mathrm{~kg} \mathrm{P} \mathrm{ha}^{-1}$ and $250-300 \mathrm{~kg} \mathrm{~K}^{-1}$ for sandy soils and $100-160 \mathrm{~kg} \mathrm{~N}^{-1} 1,40-50 \mathrm{~kg} \mathrm{P} \mathrm{ha}^{-1}$ and $200-$ $250 \mathrm{~kg} \mathrm{ha}^{-1}$ for loess. During the seventies, $60-88 \mathrm{~kg} \mathrm{~N}$ $\mathrm{ha}^{-1}$ was recommended, taking organic matter content of the soil into account. The present levels is a maximum of 50-60 $\mathrm{N} \mathrm{ha}^{-1}$, applied just before the 6-7 leaf stage when vines start absorbing N (Schaler \& Löhnerts, 1991). In Switzerland 60-80 $\mathrm{kg} \mathrm{N} \mathrm{ha}^{-1}$ is recommended on sandy soil and $50-70 \mathrm{~kg} \mathrm{~N} \mathrm{ha}^{-1}$ on medium to heavy textured soil (Anon, 1970).

For Bordeaux, Delas et al. (1982) were of the opinion that about $30 \mathrm{~kg} \mathrm{~N}^{-1}$ is an acceptable norm. They found a significant stimulation of Botrytis infection with $\mathrm{N}$ fertilisation of $100 \mathrm{~kg} \mathrm{ha}^{-1}$, but also by using the rootstock SO4. Different mechanisms were obviously involved because $\mathrm{N}$ fertilisation increased the $\mathrm{N}$ content of must, whereas this was not the case with SO4. More recently Delas (1991) reported that the aim of fertilisation in Bordeaux has changed from obtaining higher yields towards ensuring high quality. It is known that higher yields reduce quality due to lower alcohol, fewer anthocyanins and polyphenols and less aroma, i.e. an indirect effect of excessive N. In hydroponic studies where vigour and yield were kept comparable, the direct effect of high $\mathrm{N}$ nutrition were also lower alcohol, colour and anthocyanins content. In field trials increased Botrytis infection caused by high $\mathrm{N}$ levels appeared to be counteracted by $\mathrm{K}$ fertilisation. In another field trial with Merlot $\mathrm{N}$ fertilisation increased vigour but reduced yield because of berry shatter and reduced sugar and phenolic compounds, and increased the acid and $\mathrm{N}$ content of berries (Delas, 1993).

According to Winkler et al. (1974) the vineyards east of the Rocky mountains are less responsive to $\mathrm{N}$ fertilisation than those in Europe, but more so than Californian vineyards. Assuming that leaves and shoots are returned to the soil, exportations of 7,6-15,3 $\mathrm{kg} \mathrm{N}$ were calculated for a 7,8 $\mathrm{tha}^{-1}$ crop. In situations where a response can be expected, about 45-78 $\mathrm{kg} \mathrm{N}^{-1}$ was recommended, with smaller quantities of $24-45 \mathrm{~kg} \mathrm{~N} \mathrm{ha}^{-1}$ for coloured table grape cultivars such as Tokay and Emporer.

Peacock et al. (1982) found late fall (after leaf fall) $\mathrm{N}$ applications to be ineffective on Thompson Seedless on sandy soil because of leaching during winter. They admitted that the effect of early fall $\mathrm{N}$ fertilisation was still unknown and expressed doubt as to its possible unwanted stimulation of renewed shoots growth. Later work (Peacock et al., 1989) showed that veraison and after harvest $\mathrm{N}$ fertilisation of Thompson Seedless of 112 $\mathrm{kg} \mathrm{ha}^{-1}$ was more effective than budbreak $\mathrm{N}$ applications in terms of labelled $\mathrm{N}$ contents of leaf and dormant tissue, the $\mathrm{N}$ in the latter parts strongly supporting early spring growth. In another experiment Peacock et al. (1991) also found veraison and after-harvest $\mathrm{N}$ applications to be more effective than bud break and bloom applications in increasing petiole nitrate contents of Thompson Seedless, but that $\mathrm{N}$ fertilisation had no effect on Flame Seedless in this respect. Nitrogen fertilisation reduced sugar content but did not effect berry mass, acidity or $\mathrm{pH}$. Veraison or after-harvest $\mathrm{N}$ fertilisation also did not stimulate late season shoot growth.

For Australia Robinson (1992) reported only rare responses to $\mathrm{N}$ fertilisation, mainly in the raisin grape regions where yield response can be obtained with 30-60 $\mathrm{kg} \mathrm{N} \mathrm{ha}{ }^{-1}$. A negative response to $\mathrm{N}$ fertilisation with ammonium sulphate of Shiraz was ascribed to soil acidification and consequent lower $\mathrm{P}$ availability (Tulloch \& Harris, 1970; Seeliger \& French, 1971).

Up till 1920 when "complete" fertliser mixtures for vineyards were introduced, vineyards in South Africa were fertilised with August-applied farmyard manure, supplemented in certain cases with basic slag, bone meal, guano or superphosphate (Daneel, 1937; Burger, 1951). The use of these mixtures became fairly common, but this was still considered to be only additional to farmyard manure, which was progressively supplemented with sheep manure from the Karoo as vineyard plantings extended. The use of cover crops (natural weeds) in winter was encouraged to protect the soil against erosion and leaching and to serve as an indicator of the nutritional status of the soil (Burger, 1951). Daneel (1937) regarded natural weeds as lacking in fibre and recommended lupins as cover crop. He expressed doubts as to the practice of supplementing dwindling supplies of manure with straw, which may cause an $\mathrm{N}$ negative period, but stated that the incorporation of prunings into a furrow between the rows would have the desired effect. Although Reinecke (1935) found that lime and K improved the sugar content of red Muscat d'Alexandrie in Constantia, Du Toit (1937) reported that the extensive use of $\mathrm{K}$ was being stopped because its beneficial effect on quality was overrated. During and after the Second World War, fertilisers became unavailable and emphasis shifted to the use of blue lupins as cover crop to supply N.

Perold (1926) based his fertilisation recommendations for vineyards on the nutrient exporation data of Muntz and claimed that it worked well for South African conditions. He regarded manure as the best fertiliser, with $9 \mathrm{tha}^{-1}$ as adequate to satisfy the $\mathrm{N}$ and $\mathrm{K}$ needs of vineyards. Table grapes should receive more $\mathrm{N}$ and he recommended $20 \mathrm{t} \mathrm{ha}^{-1}$ manure. Malherbe (1962) quoted nutrient removal by vines of $16,3 \mathrm{~kg} \mathrm{~N}, 2,4 \mathrm{~kg} \mathrm{P}$ and 25 $\mathrm{kg} \mathrm{K}$ for a crop of $10 \mathrm{tha}^{-1}$ and recommended an annual fertilisation programme for fruit trees and wine grapes of 22-88 $\mathrm{kg} \mathrm{N}, 17-26 \mathrm{~kg} \mathrm{P}$ and $45-90 \mathrm{~kg} \mathrm{~K}$ per hectare.

For wine grapes Coetzee (1963) recommended a split application at bud break and bloom of $44 \mathrm{~kg} \mathrm{~N}, 40 \mathrm{~kg} P$ and $80 \mathrm{~kg} \mathrm{~K}$ as a normal programme. The programme of Saayman (1975) was based on nutrient removal data obtained in a field study of vineyards in the Bonnievale region (Saayman, 1973) and recommended replacement of $2,2 \mathrm{~kg} \mathrm{~N}, 0,78 \mathrm{~kg} \mathrm{P}$ and $5,0 \mathrm{~kg} \mathrm{~K}$ for each ton of grapes produced. This was subsequently updated (Saayman, 1981, 1982), using the nutrient uptake data of 
4,0 kg N, 0,7 kg P and 3,0 K per hectare for pot-grown Chenin blanc recommended by Conradie $(1980,1981)$ but restricting $\mathrm{N}$ fertilisation to a maximum of $42 \mathrm{~kg} \mathrm{ha}^{-1}$ for quality production and $100-120 \mathrm{~kg} \mathrm{ha}^{-1}$ for mass production.

In a long-term field trial at Stellenbosch only sight stimulation of shoot growth of Chenin blanc was experienced with $\mathrm{N}$ application rates of 56 and $96 \mathrm{~kg} \mathrm{ha}^{-1}$ (Conradie \& Saayman, 1989). It was estimated that the natural N-supplying capacity of the soil was nearly sufficient to satisfy the $\mathrm{N}$ demand of the vines and that only about $40 \mathrm{~kg} \mathrm{ha}^{-1}$ additional $\mathrm{N}$ was justified for the particular soil. Subsequent work of Conradie (1991) indicated that the division of absorbed $\mathrm{N}$ between permanent, vegetative and reproductive parts, $26 \%, 41 \%$ and $33 \%$ respectively, is genetically controlled and appears to remain constant for different cultivars and ages. During the budbreak-bloom phase the vine is very dependent on reserve $\mathrm{N}$. During the bloom-veraison stage most of newly absorbed $\mathrm{N}$ is diverted to the vegetation, whereas bunches receive most of their $\mathrm{N}$ from shoots, which in turn are replenished with newly absorbed $\mathrm{N}$ and not from leaves. From veraison bunches are the main accumulators of $\mathrm{N}$ from other organs (not from newly absorbed $\mathrm{N}$ ), whereas $50 \%$ of leaf $\mathrm{N}$ is translocated to permanent parts, the latter also accumulating $67 \%$ of newly absorbed $\mathrm{N}$. This pattern is probably different in cool climate countries.

For table grapes and fruit in the Western Cape, Van Niekerk \& Fourie (1951) assumed that a $30 \mathrm{t} \mathrm{ha}^{-1}$ stand of a leguminous cover crop like lupins will fix 380-544 $\mathrm{kg} \mathrm{N} \mathrm{ha}{ }^{-1}$ and will supply the necessary N,P and $\mathrm{K}$ in the desired ratio to vines and trees. If rye is used as cover crop, $35 \mathrm{~kg} \mathrm{~N} \mathrm{ha}^{-1}$ in autumn was recommended for the cover crop and $69 \mathrm{~kg} \mathrm{~N} \mathrm{ha}^{-1}$ in spring after incorporation of the cover crop. The fertilisation programme for table grapes proposed byWolf \& Van Niekerk (1959) was based on the quantities of nutrients removed by the crop and amounted to a single spring application of $244 \mathrm{~kg} \mathrm{~N}$, $36 \mathrm{~kg} \mathrm{P}$ and $163 \mathrm{~kg} \mathrm{~K}$ per hectare for a production level of $24 \mathrm{t} \mathrm{ha}^{-1}$. Van Niekerk \& Pienaar (1967) lowered these recommendations to $150 \mathrm{~kg} \mathrm{~N}, 30 \mathrm{~kg} \mathrm{P}$ and $136 \mathrm{~kg} \mathrm{~K}$ for table grapes with a production of $24 \mathrm{t} \mathrm{ha}^{-1}$, with $\mathrm{N}$ split into three equal increments at budbreak, 6 weeks later and after harvest. These recommendations were increased again by Van Niekerk et al. (1971) to $195 \mathrm{~kg} \mathrm{~N}$ $\mathrm{ha}^{-1}$ of $40 \mathrm{~kg} \mathrm{P} \mathrm{ha}^{-1}$ and $160 \mathrm{~kg} \mathrm{~K} \mathrm{ha}^{-1}$, the $\mathrm{P}$ and $\mathrm{K}$ split into two increments, applied at budbreak and after harvest. More recent $\mathrm{N}$ recommendations for table and raisin grapes were based on soil types: $120 \mathrm{~kg} \mathrm{~N} \mathrm{ha}^{-1}$ for sandy soil, $100 \mathrm{~kg} \mathrm{~N}^{-1}$ for medium to heavy textured soil and $50 \mathrm{~kg} \mathrm{ha}^{-1}$ for dark, alluvial soil, split into three increments at budbreak, bloom and immediately after harvest (Saayman, 1984).

Chambers et al. (1993) investigated the effect of 60 , 120 and $180 \mathrm{~kg} \mathrm{~N} \mathrm{ha}^{-1}$ on the incidence of Botrytis infection of Barlinka table grapes. Although little to no effect was observed in the vineyard, $\mathrm{N}$ fertilisation significant- ly increased Botrytis on grapes after cold storage, but seasonal variation was even greater. High $\mathrm{N}$ levels tended to reduce colour and to increase the incidence of dry stems.

Whereas the fertilisation of wine grapes is based on numerous studies and sound experimental data, this appears to be lacking in the case of table grapes. Here, production apparently is of higher priority than quality aspects. Also, because of a higher income gained by table grapes compared to wine grapes, higher than recommended fertilisation levels are often applied by producers. To determine the optimum $\mathrm{N}$ fertilisation level for table grapes in practice, as well as the effects of potassium and phosphourus, a long-term experiment was started in the Hex River Valley on a sandy soil, where a reaction could be expected.

\section{MATERIALS AND METHODS}

Details of the experimental lay-out have been described by Saayman \& Lambrechts (1995) and only relevant aspects are presented here. The soil was a grayish, almost pure sand, containing about $5 \%$ silt plus clay, $0,5 \%$ organic $\mathrm{C}, 22 \mathrm{mg} \mathrm{P} \mathrm{kg}^{-1}$ and $19 \mathrm{mg} \mathrm{K} \mathrm{kg}^{-1}$. The experimental vineyard was planted in 1978, all plots initially receiving $45 \mathrm{~kg} \mathrm{~N} \mathrm{ha}^{-1}$ dissolved in the irrigation water that was applied by drippers and micro-sprinklers. From the 1978/79 season weekly-applied differential $\mathrm{N}$ fertilisation levels of 24,48 and $72 \mathrm{~kg} \mathrm{~N} \mathrm{ha}^{-1} \mathrm{yr}^{-1}$ were applied and factorially combined with two different seasonal patterns of $\mathrm{N}$ application, two irrigation systems and three crop levels, all treatments replicated four times. These $\mathrm{N}$ levels were increased to 35,70 and 105 $\mathrm{kg} \mathrm{N} \mathrm{ha-1} \mathrm{yr}^{-1}$ during 1980/81 and from 1985/86 to 60, 120 and $180 \mathrm{~kg} \mathrm{~N} \mathrm{ha}^{-1} \mathrm{yr}^{-1}$. One seasonal $\mathrm{N}$ application pattern consisted of $67 \%$ of total $\mathrm{N}$ applied from commencement of irrigation (usually mid-October, 2-3 weeks before bloom) until January (2-3 weeks before veraison), and the remaining $33 \%$ over a 4 week period immediately after harvest. In the other $\mathrm{N}$ application pattern total $\mathrm{N}$ was split equally between these two periods.

The three crop levels were 15, 22 and 29 bunches vine $^{-1}$ from the 1984/85 season. Because of a diminishing availability of data vines that were free of 'red leaf' (Saayman \& Lambrechts 1993), the experimental lay-out was reduced during the two final seasons, inter alia by abandoning the 50:50 seasonal $\mathrm{N}$ application pattern treatment and retaining only the 22 bunches vine ${ }^{-1}$ crop level.

Initially bypass fertilisation tanks were used to apply the $\mathrm{N}$ fertiliser, but from 1983/84 they were replaced with water-powered, diaphragm dosage pumps, which were in turn replaced by electrically driven dosage pumps before the 1990/91 season. The N source used was initially aqueous urea, but was replaced with liquid ammonium nitrate $(19 \% \mathrm{~N})$ from 1985 in response to the findings of Du Preez (1983) that urea is less efficient on soils which have less than $6 \%$ clay, a low $\mathrm{pH}$ and a low organic material content. 
On a split plot basis, superphosphate and $\mathrm{KCl}$ were deeply incorporated during soil preparation as stock fertilisation with the aim of increasing the $\mathrm{P}$ and $\mathrm{K}$ concentrations in the soil to $50 \mathrm{mg} \mathrm{kg}^{-1}$ and $100 \mathrm{mg} \mathrm{kg}^{-1}$ respectively. Because of generally low $\mathrm{K}$ concentrations detected in the soil and leaves, differential $\mathrm{K}$ fertilisation was eventually abandoned and a blanket application of 250 $\mathrm{kg} \mathrm{ha}^{-1}$ in the form of $\mathrm{KCl}$ applied on the soil surface before the 1982/83 season. From 1986/87 a blanket amount of $200 \mathrm{~kg} \mathrm{ha}^{-1} \mathrm{yr}^{-1}$ dissolved $\mathrm{KCl}$ was applied in the same manner as for $\mathrm{N}$.

Grapes were harvested at $17-18^{\circ} \mathrm{B}$, weighed and the colour of bunches assessed on a 1-6 scale, with 1 being almost black and 6 almost green. For each plot a carton of export quality grapes was packed, protected by a paper $\mathrm{SO}_{2}$ generator, and stored at $-0,5^{\circ} \mathrm{C}$ for four weeks, followed by one week at $10^{\circ} \mathrm{C}$. After this, grapes were evaluated for greenness of stems, cracking of berries, Botrytis infection and $\mathrm{SO}_{2}$ damage. The sugar and acid contents of berries were measured, using standard Nietvoorbij methods. Shoot mass was determined by weighing winter prunings.

Data were subjected to analysis of variance, using Genstat and Statgraphics software. Because repetitions and treatments changed during the duration of the trial, treatment means, using seasons as repetitions in time, were compared in order to obtain indications of the mean long-term or cumulative effect of treatments.

\section{RESULTS AND DISCUSSION}

Shoot Growth: Throughout the 12 years of measurements, no significant effect of seasonal $\mathrm{N}$ application pattern on shoot growth was found for individual seasons (data not shown). Concerning the mean long-term effect, it was found that the $67: 33 \mathrm{~N}$ application pattern slightly $(3 \%)$ but highly significantly $(\mathrm{P}=0,0002)$ increased shoot growth compared to the 50:50 pattern. On the strength of this result, when the experimental layout had to be reduced from 1990/91, the 50:50 N pattern treatment was dropped.

Increasing $\mathrm{N}$ fertilisation levels almost consistently increased shoot growth significantly (Fig. 1), the considerable seasonal variation mainly caused by variations in crop load (Saayman \& Lambrechts, 1995). During the period of low $\mathrm{N}$ levels (1981-1985), in three out of five seasons, $70 \mathrm{~kg} \mathrm{~N} \mathrm{ha}^{-1}$ appeared to be too little to significantly increase shoot growth over the lowest rate of 35 $\mathrm{kg} \mathrm{N} \mathrm{ha}^{-1}$, whereas an amount of $105 \mathrm{~kg} \mathrm{~N} \mathrm{ha}^{-1}$ was consistently superior to $35 \mathrm{~kg} \mathrm{~N}^{-1}$ during all five low- $\mathrm{N}$ levels seasons. When $\mathrm{N}$ levels were increased from

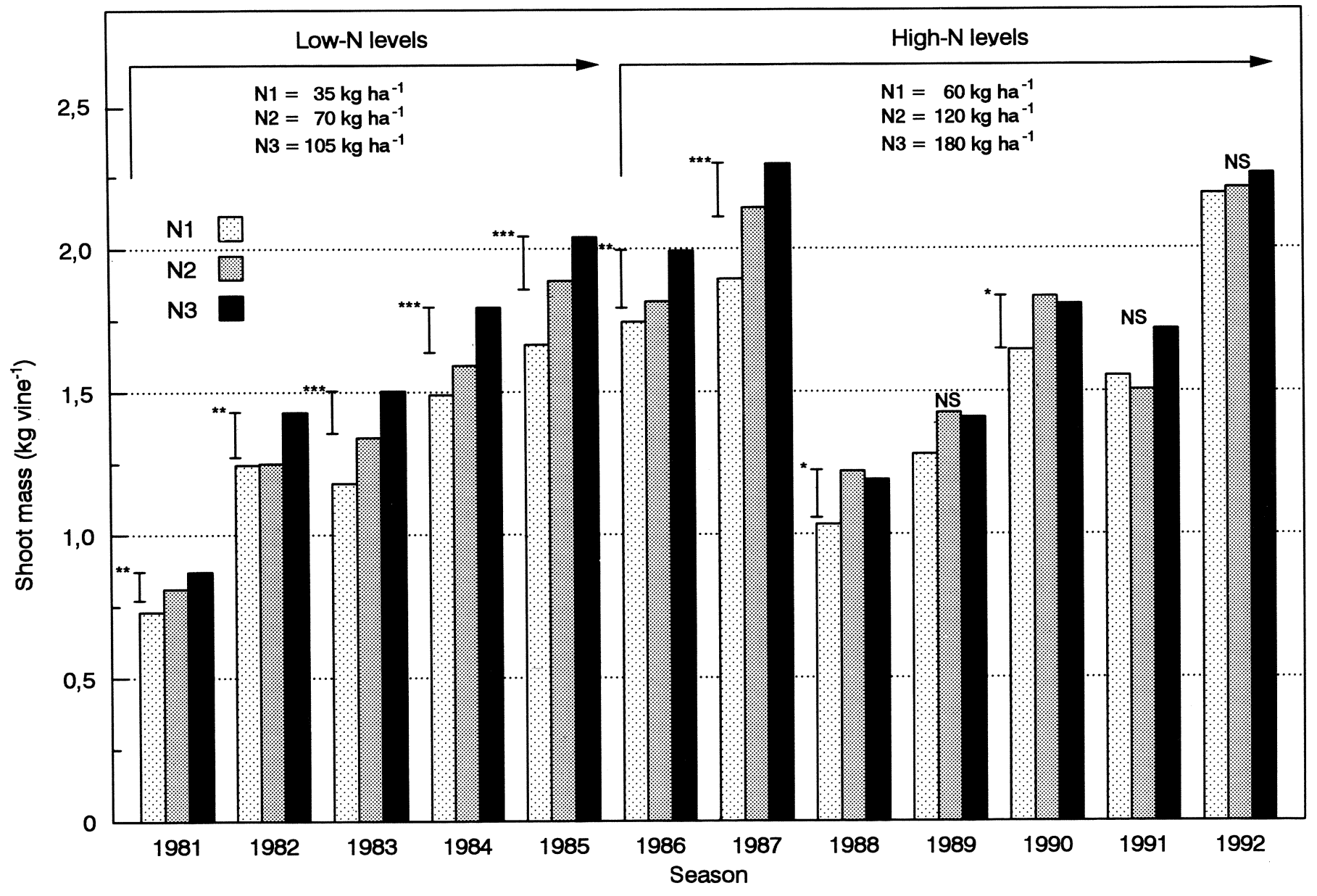

FIGURE 1

Effect of $\mathrm{N}$ level on the vigour of Barlinka/Ramsey on sandy soil, Nietvoorbij Experimental Farm, De Doorns, Hex River Valley. 
1985/86 an N level of $180 \mathrm{~kg} \mathrm{ha}^{-1}$ initially induced a significantly higher shoot mass than $60 \mathrm{~kg} \mathrm{~N} \mathrm{ha}^{-1}$, as well as $120 \mathrm{~kg} \mathrm{~N} \mathrm{ha}^{-1}$ during 1986/87. After this responses were erratic, $120 \mathrm{~kg} \mathrm{~N} \mathrm{ha}^{-1}$ often appearing to be superior to $180 \mathrm{~kg} \mathrm{~N} \mathrm{ha}^{-1}$.

To cope with the change in $\mathrm{N}$ levels from 1985/86 when estimating the long-term effect of the different $\mathrm{N}$ levels, the $60 \mathrm{~kg} \mathrm{~N} \mathrm{ha}^{-1}$ treatment of the initial low-N levels period was assumed to be comparable to the $70 \mathrm{~kg} \mathrm{~N}$ ha $^{-1}$ treatment of the second high- $\mathrm{N}$ levels period. This $60-70 \mathrm{~kg} \mathrm{~N}^{-1}$ level was then taken as a reference $\mathrm{N}$ rate which overlapped the two $\mathrm{N}$ level periods. According to Fig. 2 shoot mass increased up to an N level of $105 \mathrm{~kg} \mathrm{~N}$ $\mathrm{ha}^{-1}$, from where no further significant increases occurred, indicating that for this trial, with a mean production of about $30 \mathrm{t} \mathrm{ha}^{-1}$, about $100 \mathrm{~kg} \mathrm{~N} \mathrm{ha}^{-1}$ was optimum for shoot growth. This is less than half the $244 \mathrm{~kg}$ ha ${ }^{-1}$ originally proposed by Wolf \& Van Niekerk (1959) for table grapes and considerably less than the 150-195 $\mathrm{kg} \mathrm{ha}^{-1}$ advised by the former Fruit \& Fruit Technology Research Institute (Van Niekerk \& Pienaar, 1967; Van Niekerk, Terblanche \& Deist, 1971), which was responsible for table grape research in South Africa until the end of 1981. It is also less than the $120 \mathrm{~kg} \mathrm{ha}^{-1} \mathrm{~N}$ that was subsequently calculated to be sufficient for table and raisin grapes on sandy soil (Saayman, 1984). This optimum amount of $\mathrm{N}$ fertilisation is expected to be still lower for heavier textured soils with their greater $\mathrm{N}$ minilisation and nutrient retention capacities.

A stock fertilisation of $\mathrm{P}$ and $\mathrm{K}$ before planting did not have a significant effect on shoot growth in individual seasons (data not shown). However, cumulatively over the 12 year duration of the trial significant mean increase in shoot growth was obtained ( $P=0,0073)$. However, this stimulation of shoot growth by $\mathrm{P}$ and/or $\mathrm{K}$ was very small (from 1,569 to $1,603 \mathrm{~kg}^{\text {vine }} \mathrm{e}^{-1}$ ) and probably has few practical implications. The experimental design did not allow a distinction to be made between $\mathrm{P}$ and $\mathrm{K}$. Because the $\mathrm{K}$ content of the soil could not be increased to or maintained at the target level of $100 \mathrm{mg}$ $\mathrm{kg}^{-1}$, a blanket amount of $250 \mathrm{~kg} \mathrm{~K} \mathrm{ha}{ }^{-1}$ was surface applied before the 1982/83 season and from 1986, $90 \mathrm{~kg}$ $\mathrm{K} \mathrm{ha}^{-1}$ each season through the irrigation systems. In view of this the slight long term stimulation of shoot growth can most probably be ascribed to the effect of $\mathrm{P}$. Reports on responses of vines to $\mathrm{P}$ fertilisation are rare in the literature. In Australia growth and yield responses of Shiraz were obtained only after eight years of P fertilisation. The increased yield was ascribed to more berries per bunch (Tulloch \& Harris, 1970). On coastal sand in southern France, Champagnol (1978b) found that P fertilisation improved vigour and alleviated leaf symptoms of chloride injury. He proposed that the more than threefold increase in fresh material of the barley cover crop

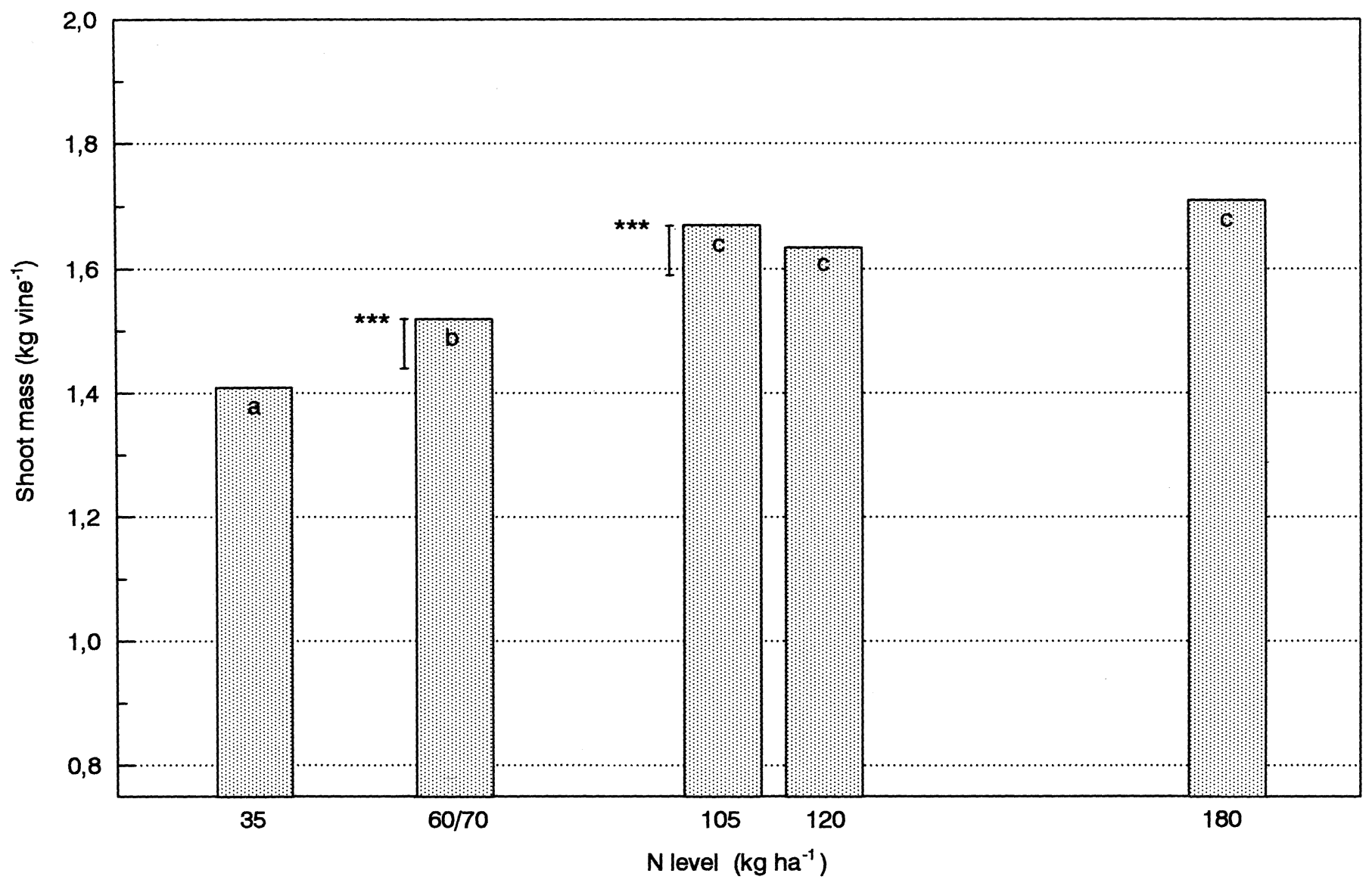

FIGURE 2

Long-term effect of $\mathrm{N}$ level on shoot growth of Barlinka/Ramsey, Nietvoorbij Experimental Farm, De Doorns, Hex River Valley. 
due to P fertilisation may have contributed to this result. In South Africa no seasonal response of Chenin blanc to $\mathrm{P}$ fertilisation was observed, but a cumulative response in terms of both shoot growth and yield over an 11 year period could be demonstrated (Conradie \& Saayman, 1989).

Yield and Quality: Compared to the 50:50 seasonal $\mathrm{N}$ application pattern, the 67:33 pattern increased bunch mass significantly in one out of the five low-N levels seasons. Higher yields were obtained during four out of five high $\mathrm{N}$ levels seasons and colour was negatively affected by the $67: 33 \mathrm{~N}$ application pattern only in the 1986/87 season (data not shown).

The mean effects on crop characteristics over the 10 year period when differential seasonal $\mathrm{N}$ patterns were applied are shown in Table 1. Because bunch number per vine was controlled and did not differ between $\mathrm{N}$ application patterns, the higher mean crop mass per vine obtained with the $67: 33 \mathrm{~N}$ application pattern can be assumed to be the result of larger bunches than was the case with the 50:50 $\mathrm{N}$ application pattern. The larger bunches can in their turn be ascribed to more berries per bunch, as berry mass did not differ between treatments, indicating improved berry set. However, these differences were small, in practice amounting to a mean gain of about $0,73 \mathrm{tha}^{-1}$.

Conradie (1991) found that Chenin blanc bunches receive $\mathrm{N}$ during the bloom-veraison phase mostly from shoots and not from leaves, the shoots in their turn being replenished by newly absorbed $\mathrm{N}$. The higher $\mathrm{N}$ dosage during the bloom-preharvest period by the $67: 33 \mathrm{~N}$ application pattern probably allowed greater transfer of $\mathrm{N}$ to bunches via this $\mathrm{N}$ distribution pattern, stimulating increased berry set. The slight (3\%) mean shoot growth stimulation obviously had no negative effect in this regard. Although sugar content of berries was not negatively affected by the higher preharvest $\mathrm{N}$ dosage, acid concentrations were increased, but did not effect packing or export quality.

Concerning $\mathrm{N}$ application levels, in two out of the five initial low-N levels seasons, the highest $105 \mathrm{~kg} \mathrm{ha}^{-1}$ level increased crop mass significantly over the lowest 35 $\mathrm{kg} \mathrm{N} \mathrm{ha}{ }^{-1}$ level. During one of these seasons it was also superior to the intermediate $70 \mathrm{~kg} \mathrm{~N} \mathrm{ha}^{-1}$ level. During the following seven high-N levels seasons, the highest level of $180 \mathrm{~N} \mathrm{ha}^{-1}$ increase crop mass significantly over the two lower $\mathrm{N}$ levels during two seasons. These increases could largely be ascribed to increased bunch masses (data not shown). Colour was negatively affected only once by a level of $180 \mathrm{~kg} \mathrm{~N} \mathrm{ha}^{-1}$ and did not coincide with an increased bunch or crop mass, whereas the effect of $\mathrm{N}$ levels on the amount of grapes having packing or export quality was irregular and inconsistent (data not shown).

To evaluate the long-term effect of $\mathrm{N}$ levels on production and grape quality parameters, the same procedures was followed as described above for shoot growth. According to Table 2 the highest bunch mass was obtained with $105 \mathrm{~kg} \mathrm{~N} \mathrm{ha}^{-1}$, still higher $\mathrm{N}$ levels having no additional effect. This was largely reflected in crop mass. However, berry mass seems to be negatively

\section{TABLE 1}

Mean effect of nitrogen application pattern over a 10-year period on production and quality parameters of Barlinka/ Ramsey; Nietvoorbij Experimental Farm, De Doorns, Hex River Valley.

\begin{tabular}{|c|c|c|c|}
\hline $\begin{array}{l}\text { Parameter } \\
\text { measured }\end{array}$ & \multicolumn{2}{|c|}{$\begin{array}{l}\mathrm{N} \text { application pattern } \\
67: 33 \quad 50: 50\end{array}$} & $\begin{array}{l}\text { Significance } \\
\text { level }(\mathrm{P})\end{array}$ \\
\hline Bunch mass (g) & 600,2 & 587,1 & 0,0036 \\
\hline Crop mass $\left(\mathrm{kg}\right.$ vine $\left.\mathrm{e}^{-1}\right)$ & 10,45 & 10,12 & 0,0110 \\
\hline Berry mass (g) & 6,69 & 6,61 & 0,1815 \\
\hline Colour rating* & 2,03 & 2,01 & 0,4291 \\
\hline Sugar conc. $\left({ }^{\circ} \mathrm{B}\right)$ & 17,25 & 17,42 & 0,1235 \\
\hline Acid conc. $(\%)$ & 0,467 & 0,450 & 0,0359 \\
\hline Bunches packed (\%) & 78,4 & 77,5 & 0,0676 \\
\hline Export quality (\%) & 42,6 & 42,2 & 0,5405 \\
\hline
\end{tabular}

* Evaluated on a $1-6$ scale, with $1=$ well coloured and $6=$ almost green.

67:33 67\% of total $\mathrm{N}$ applied during pre-bloom to véraison; $33 \%$ during four weeks after harvest.

50:50 50\% of total $\mathrm{N}$ applied during pre-bloom to véraison; $50 \%$ during four weeks after harvest. 
affected by the high $180 \mathrm{~kg} \mathrm{~N}$ ha' level. The bunch mass of this treatment was comparable to that of the $105 \mathrm{~kg} \mathrm{~N}$ $\mathrm{ha}^{-1}$ level, which implies that, in the absence of excessively stimulated shoot growth (Fig 2), the high $\mathrm{N}$ level also increased berry set, but in this case to the detriment of eventual berry size.

Colour and sugar content of berries were negatively affected by $\mathrm{N}$ levels higher than $105 \mathrm{~kg} \mathrm{~N} \mathrm{ha}^{-1}$ and 120 $\mathrm{kg} \mathrm{N} \mathrm{Na}^{-1}$ respectively, but this, together with reduced berry size, apparently was of such negligible magnitude that it had no appreciable impact on grapes classed as fit for packing or export. Chambers et al. (1993) also found that high $\mathrm{N}$ fertilisation levels caused reduced colouring of Barlinka grapes.

No significant effects of stock $\mathrm{P}$ and $\mathrm{K}$ fertilisation on crop characteristics could be identified. The fact that these treatments were applied on a split plot basis, making statistical testing for significance in differences of means less sensitive, may have contributed to this lack of results.

Storage characteristics: Out of the eight seasons when effects of $\mathrm{N}$ application patterns on quality aspects of cold stored grapes were measured, the 67:33 pattern only once had a positive significant effect on greenness of stems and neck cracking (not in the same season) respectively compared to the 50:50 $\mathrm{N}$ application pattern (data not shown). Evaluated over the duration of the trial, the 67:33 $\mathrm{N}$ application pattern had a very slight positive mean effect of the greenness of stems $(2 \%)$, but had no significant effect on berry cracking, $\mathrm{SO}_{2}$ or Botrytis damage, compared to the $50: 50 \mathrm{~N}$ application pattern (data not shown).

In two out of the 10 seasons when effects of different $\mathrm{N}$ levels were measured, the higher $\mathrm{N}$ level(s) had a slight positive effect on greenness of stems and reduced neck cracking during two other seasons (data not shown). According to the long-term mean effects shown in Table 3, the high $\mathrm{N}$ levels were slightly more effective in preserving greenness of bunch stems after cold storage, but had no siginificant effect on the other quality parameters measured. The indications of a positive effect of the higher pre-harvest $\mathrm{N}$ dosages or $\mathrm{N}$ levels on greenness of stems after cold storage have no logical explanation and are contrary to the findings of Chambers et al. (1993).

Botrytis was never a serious problem over the duration of the trial and even when grapes were stored without $\mathrm{SO}_{2}$ protection during 1992, no effect of $\mathrm{N}$ level was obtained (data not shown). Chambers et al. (1993) found

TABLE 2

Mean effect of nitrogen application level over a 10-year period on production and quality parameters of Barlinka / Ramsey; Nietvoorbij Experimental Farm, De Doorns, Hex River Valley.

\begin{tabular}{|l|ccccc|c|}
\hline \multirow{1}{*}{$\begin{array}{c}\text { Parameter } \\
\text { measured }\end{array}$} & \multicolumn{7}{c|}{ N application level $\left(\mathrm{kg} \mathrm{ha}^{-1}\right)^{*}$} & Significance \\
level(P)
\end{tabular}

* a,b: Figures in rows followed by the same symbols do not differ significantly $(\mathrm{p} \leq 0,05)$.

$* *$ Evaluated on a $1-6$ scale, with $1=$ well coloured and $6=$ almost green .

TABLE 3.

Mean effect of nitrogen application level over a 10-year period on quality parameters of Barlinka grapes after cold storage.

\begin{tabular}{|c|c|c|c|c|c|c|}
\hline \multirow{2}{*}{$\begin{array}{c}\text { Parameter } \\
\text { measured }\end{array}$} & \multicolumn{5}{|c|}{$\mathrm{N}$ application level $\left(\mathrm{kg} \mathrm{ha}^{-1}\right) *$} & \multirow{2}{*}{$\begin{array}{c}\text { Significance } \\
\text { level(P) }\end{array}$} \\
\hline & 35 & $60 / 70^{1}$ & 105 & 120 & 180 & \\
\hline Green stems (\%) & $46,1 \mathrm{a}$ & $46,9 \mathrm{a}$ & $47,6 a b$ & $48,5 b c$ & $50,0 \mathrm{c}$ & 0,0027 \\
\hline Botrytis rot (\%) & $0,67 \mathrm{a}$ & $0,71 \mathrm{a}$ & $0,73 a$ & $0,86 a$ & $1,07 \mathrm{a}$ & 0,3263 \\
\hline Neck cracks $(\%)$ & $5,11 \mathrm{a}$ & $5,05 \mathrm{a}$ & $5,26 a$ & $4,70 \mathrm{a}$ & $4,19 a$ & 0,0534 \\
\hline Ordinary cracks $(\%)$ & $0,051 \mathrm{a}$ & $0,027 \mathrm{a}$ & $0,032 \mathrm{a}$ & $0,036 \mathrm{a}$ & $0,041 \mathrm{a}$ & 0,3281 \\
\hline $\mathrm{SO}_{2}(\%)$ & $0,20 \mathrm{a}$ & $0,22 \mathrm{a}$ & $0,24 a$ & $0,23 \mathrm{a}$ & $0,21 \mathrm{a}$ & 0,8269 \\
\hline Total damage (\%) & $6,12 \mathrm{a}$ & $6,13 \mathrm{a}$ & $6,49 a$ & $5,94 a$ & $5,63 a$ & 0,3732 \\
\hline Firmness (\%) & $85,4 a$ & $85,0 \mathrm{a}$ & $84,9 \mathrm{a}$ & $82,6 \mathrm{a}$ & $82,1 \mathrm{a}$ & 0,1560 \\
\hline
\end{tabular}

a,b: Figures in rows followed by the same symbols do not differ significantly $(p \leq 0,05)$. 
that $\mathrm{N}$ fertilisation increased Botrytis rot damage but that this was overshadowed by seasonal effects. Clearly certain conditions prevailing in a specific vineyard (locality, foliage density, row orientation, sanitary measures) are predominant in determining its susceptibility to Botrytis and may override any $\mathrm{N}$ effect, as was probably the case in this trial.

Crop Load: The pronounced depressing effect of increasing crop load on shoot growth have already been reported (Saayman \& Lambrechts, 1995). High crop loads also significantly decreased bunch mass regularly from 1983 as well as colour of bunches during all of the ten seasons when it was measured and sugar concentration in berries in two out of the eight seasons of measurement (data not shown). The mean long-term effects of increasing crop load were also smaller bunches, weaker colouring and lower sugar concentrations, culminating in less grapes of packing and export quality (Table 4). For the mean shoot mass of $1,822 \mathrm{~kg}$ vine $^{-1}$ of this trial and using the formula proposed by Saayman \& Lambrechts (1995), a balanced crop load would be 22 bunches per vine, which in terms of the parameters in Table 4 may already be too high for the best quality.

Compared to the data in Table 2, it is evident that the negative effect of a high crop load was comparable to that of too high $\mathrm{N}$ levels in terms of bunch mass and colour. A too high crop load is apparently even more detrimental in terms of grapes suitable for packing or export than too high $\mathrm{N}$ levels. If a crop load of 18-19 bunches vine ${ }^{-1}$ is assumed to be compatible with acceptable quality, this would have ensured a production of $26,7 \mathrm{t} \mathrm{ha}^{-1}$ in this trial. This is more than sufficient to pack 4000 cartons of grapes, leaving a margin of $25 \%$ grapes not suitable for packing.

TABLE 4

Mean effect of crop load over a period of 10 seasons on some characteristics of Barlinka bunches; Nietvoorbij Experimental Farm, De Doorns, Hex River Valley.

\begin{tabular}{|c|c|c|c|c|}
\hline Parameter & \multicolumn{3}{|c|}{ Crop load (bunches vine ${ }^{-1}$ ) } & Significance \\
\hline measured & 15 & 22 & 29 & level (P) \\
\hline Bunch mass (g) & $629 a$ & $587 \mathrm{~b}$ & $565 c$ & 0,0000 \\
\hline Berry mass (g) & $6,62 \mathrm{a}$ & $6,67 \mathrm{a}$ & 6,67 & 0,5750 \\
\hline Colour rating* & $1,797 \mathrm{a}$ & $2,067 \mathrm{~b}$ & $2,180 \mathrm{~b}$ & 0,0000 \\
\hline Sugar conc. $\left({ }^{\circ} \mathrm{B}\right)$ & $17,50 \mathrm{a}$ & $17,29 a b$ & $17,12 b$ & 0,0120 \\
\hline Acid conc. $(\%)$ & $0,452 \mathrm{a}$ & $0,460 \mathrm{a}$ & $0,454 \mathrm{a}$ & 0,0856 \\
\hline Bunches packed (\%) & $83,5 \mathrm{a}$ & $77,0 \mathrm{~b}$ & $73,4 b$ & 0,0003 \\
\hline Export quality (\%) & $48,7 \mathrm{a}$ & $42,7 b$ & $37,2 \mathrm{c}$ & 0,0006 \\
\hline
\end{tabular}

a,b: Figures in rows followed by the same symbols do not differ significantly ( $\mathrm{p} \leq 0,05)$.

* Evaluated on a $1-6$ scale, with $1=$ well coloured and $6=$ almost green.

\section{CONCLUSIONS}

This trial succeeded in demonstrating the positive effect of $\mathrm{N}$ fertilisation of Barlinka on sandy soil. Strong evidence was obtained that under the adaphic, genetic and crop load restrictions of this trial, an amount of about $100 \mathrm{~kg} \mathrm{~N} \mathrm{ha}^{-1}$ was optimum in terms of shoot growth and grape quality. It can be assumed that this quantity would be less for heavier textured or more organically rich soils with their greater $\mathrm{N}$ mineralisation capacities. It also appeared that the concentration of total seasonal $\mathrm{N}$ dosages in the pre-bloom to veraison period had a slight beneficial effect on shoot growth, compared to a more even distribution over the season. Because shoot growth was not excessively stimulated by this treatment, it also appeared to be beneficial to berry set, resulting in a slightly increased crop mass. However, indications were also obtained that excessively improved berry set caused by too high $\mathrm{N}$ levels leads to smaller berries, loss of colour and reduced sugar concentrations and consequently to losses in terms of grapes suitable for packing.

Applying a stock fertilisation of $\mathrm{K}$ cannot be recommended on this sandy soil because of the soil's inability to absorb and retain sufficient quantities of $\mathrm{K}$. It is recommended that $\mathrm{K}$ be applied through the irrigation systems in the same manner as $\mathrm{N}$ from pre-bloom 
to veraison and for four weeks after harvest. The indications obtained that $\mathrm{P}$ had a slight long-term positive effect on shoot growth apparently have very few practical implications.

Apart from previously reported marked depressive affects of crop load on shoot growth, too high crop loads have marked negative effects on grape quality, comparable to those of excessive $\mathrm{N}$ fertilisation, especially in terms of bunch mass, colour and sugar content of berries, resulting in a significant reduction in grapes suitable for packing. For the conditions of this trial a crop load of 22 bunches vine- ${ }^{-1}$ (about 6 bunches $\mathrm{m}^{-2}$ trellising surface) was calculated to be in balance with the mean $1,822 \mathrm{~kg}$ vine $^{-1}$ vigour, whilst a crop load of 18-19 bunches vine (about 5,25 bunches $\mathrm{m}^{-2}$ trellising surface) appeared to be optimum for grape quality.

\section{LITERATURE CITED}

ANON., 1970. La fumure de la vigne. Norme pour la suisse romand. Revue suisse de viticulture et d'arboriculture 11(6), 127-131.

BURGER, R., du T., 1951. Die invloed van bemesting op die opneembare stikstof in twee grondtipes onder wingerd. M.Sc thesis, University of Stellenbosch, 7600 Stellenbosch.

CHAMBERS, K.R., VAN DER MERWE, G.G., FOURIE, J.F. \& FERRANDI, C., 1993. Botrytis rot of table grapes as influenced by different levels of nitrogen applied to soil. Decid. Fruit Grow. 43(2), 64-67.

CHAMPAGNOL, F., 1971. Etude de quelques effects de la fertilisation azotée sur la vigne. Extrait du Progrès agric. vitic. 88(9-21), 1-57.

CHAMPAGNOL, F., 1978a. Fertilisation optimal de la vigne. Progrès agric. vitic. 95(15-16), 423-440.

CHAMPAGNOL, F., 1978b. Quelques problèms des vignobles des sables littoraux méditerranéens, Progrès agric. vitic. 95(24), 677-686.

COETZEE, J.H.L., 1963. The fertilisation of grape vines. Wynboer Aug., 20-21.

CONRADIE, W.J., 1980. Seasonal uptake of nutrients by Chenin blanc in sand culture: I. Nitrogen. S. Afr. J. Enol. Vitic. 9(1), 59-65.

CONRADIE, W.J., 1981. Seasonal uptake of nutrients by Chenin blanc in sand culture: II. Phosphorus. potassium, calcium and magnesium. S. Afr. J. Enol. Vitic. 2(1), 7-13.

CONRADIE, W.J., 1991. Translocation and storage of nitrogen by grapevines as affected by time of application. In: RANTZ, J.M. (ed). Int. Symp. on Nitrogen in Grapes and Wine, 1991, Seattle, USA, pp. 32-42.

CONRADIE, W.J., \& SAAYMAN, D., 1989. Effects of long-term nitrogen, phorphorus and potassium fertilisation on Chenin blanc vines. I Nutrient demand and vine performance. Am. J. Enol. Vitic. 40(2), 85-90.

DANEEL, P., 1937. Paarl gronde en tafeldruiwer-produksie. M.Sc. thesis, University of Stellenbosch, 7600 Stellenbosch.

DELAS, J., 1991. La nutrition minirale de la vigne. Expériences en France. OIV Group d'experts: 'Physiology de la vigne', Dec. 1991, Paris. pp. 1-9.

DELAS, J., 1992. La méthodologie de l'expérimentation viticole en matière de fertilisation. Progrès agric. vitic. 109(1), 9-12.

DELAS, J., 1993. Nutrition azotée. Composition des baies et des moûts. Progrès agric. vitic. 110(6), 139-142.

DELAS, J., MOLOT, C. \& SOYER, J.P., 1982. Influence d'une fertilisation agotée excessive, du porte-greffe et de la charge sur la sensibilité du cepage Merlot à Botrytis cinerea. Bull OEPP 12(2), 177-182.

DELAS, J., 1971. Fertilisation de la vigne. In: RIBEREAU-GAYON, J. \& PEYNAUD, E (eds.) Sciences et techniques de la vigne. Dunod, Paris. pp. 617-649.

DU PREEZ, M., 1983. Hidrolise, nitrifikasie en vervlugting van ureum onder gekontroleerde toestande in dominante grondtipes van die WesKaap. M.Sc. thesis, University of Stellenbosch, 7600 Stellenbosch.

DU TOIT, A.J., 1937. Groeiverhoudings en chemiese veranderinge by Waltham Cross. M.Sc. thesis, University of Stellenbosch, 7600 Stellenbosch.

LAFON, J., COUILLARD, P. \& GAY-BELLE, F., 1965. Rhytme de l'absorption minerale de la vigne au cours d'un cycle vegetatif. Vignes et Vins. 140,17-21

MALHERBE, I. de V., 1962. Grondvrugbaarheid. Leerboek oor landbouchemie. Nasionale Opvoedkundige Uitgewery Bpk., Kaapstad.

MAROCKE, R., BALTHAZARD, J. \& HUGLIN, P., 1977. Data concerning the uptake of fertilizing elements by the vine and a fertilisation experiment. Int. Symp. on the Quality of the Vintage, 14-16 Feb. 1977, Cape Town. Nietvoorbij Research Institute, Stellenbosch, R.S.A.

PEACOCK, W.L. BROADBENT, F.E. \& CHRISTENSEN, L.P., 1982. Late-fall nitrogen application in vineyards is inefficient. Calif. Agric, Jan.-Feb., 22-23.

PEACOCK, W.L., CHRISTENSEN, L.P. \& BROADBENT, F.E., 1989. Uptake, storage, and utilisation of soil-applied nitrogen by Thompson Seedless as affected by time of application. Am. J. Enol. Vitic. 40(1), 16-20. PEACOCK, W.L., CHRISTENSEN, L.P. \& HIRSCHEFELT, D.J., 1991. Influence of timing of nitrogen fertilizer application on grapevines in the San Joaquin Valley. Am. J. Enol Vitic. 42(4), 322-326.

PEROLD, A.I., 1926. Handboek oor wynbou. Pro Ecclecia Drukkery, Stellenbosch.

REINECKE, V., 1935. Die Kultuur von Tafeltrauben in Südafrika. Ernähr. Pfl. 31, 313-316. (Abstract: Hort. Abstr. 6:48, 1935).

ROBINSON, J.B., 1992. Grapevine nutrition. In: COOMBE, B.G. \& DRY, P.R. (Eds.). Viticulture, Vol.2, Practices. Winetitles, Underdale, Australia. pp. 178-208.

SAAYMAN, D., 1973. Grondeieskappe en wingerprestasie in die Bonnievale-omgewing. M.Sc. thesis, University of Stellenbosch, 7600 Stellenbosch.

SAAYMAN, D., 1975. Bemesting volgens opbrengs en grondtipe. Boerdery in Suid-Afrika, Wynkunde en Wingerdbou E.3/1975, 1-4.

SAAYMAN, D., 1981. Wingerdvoeding. In: BURGER, J. \& DEIST, J. (eds.). Wingerdbou in Suid-Afrika. Nietvoorbij. P/Bag X5026, 7599 Stellenbosch, R.S.A. pp. 341-383.

SAAYMAN D., 1984, N, P and K fertilisation of table and raisin grapes. Farming in South Africa, Viticulture and Oenology E. 17/1984, 1-8.

SAAYMAN, D. \& LAMBRECHTS, J.J.N., 1993. The possible cause of Red Leaf disease and its effect on Barlinka table grapes. S. Afr. J. Enol. Vitic. 14(2), 26-32.

SAAYMAN, D. \& LAMBRECHTS, J.J.N., 1995. The effect of irrigation system and crop load on the vigour of Barlinka table grapes on a sandy soil, Hex River Valley. S. Afr. J. Enol. Vitic. 16(2) 26-34.

SCHALLER, K. \& LÖHNERTZ, O., 1991. Nutrition minérale de la vigne Expériences en Allemagne. OIV Groupe d'experts: Physiologie de la Vigne'. Dec. 1991, Paris. pp 1-14.

SEELIGER, M.T. \& FRENCH, R.J., 1971. Changes in soil chemical properties in a long-term fertilizer trial in a non-irrigated vineyard. Aust. $J$. Agric. Res. 22, 931-940

TULLOCH, H.W. \& HARRIS, W.B., 1970. Fertiliser responses with nonirrigated Shiraz grapevines. 1944-1966. Aust. J. Agric. Res. 21, 243-252.

VAN NIEKERK, P.E. le R \& FOURIE, D., 1951. Die bemesting van vrugtebome en tafeldruiwe. Sagtevrugboer 1(4), 16-18.

VAN NIEKERK, P.E. le R. \& PIENAAR., P.J., 1967. Bemestingsprogram vir vrugtebome en tafeldruiwe in die Winterreënstreek. Sagtevrugteboer 17 (5), 141-148.

VAN NIEKERK, P.E. le R., TERBLANCHE, J.H. \& DEIST, J., 1971. Anorganiese bemesting van sagtevrugte. NIVV Inligtingsbulletin nr. 33. FFTRI, P/Bag 5013, 7599 Stellenbosch.

WINKLER, A.J., COOK, J.A., KLIEWER, W.M. \& LIDER, L.A., 1974. General viticulture. Univ. Calif. Press, Berkeley, California.

WOLF, E. \& VAN NIEKERK, P.E. le R., 1959. Bemestingsprogram vir vrugtebome en tafeldruiwe van die Winterreenstreek. Sagtevrugteboer Aug., 243-251. 